\title{
Impact of sawdust on the water quality of Elechi creek in Port Harcourt municipality
}

\author{
C.C. OBUNWO ${ }^{1 *}$, S.A. BRAIDE $^{2}$ and A.C. CHINDAH ${ }^{2}$ \\ ${ }^{1}$ Department of Chemistry, Rivers State University of Science and Technology, Nkpolu- Oroworukwo, \\ Port Harcourt. \\ ${ }^{2}$ Institute of Pollution Studies, Rivers State University of Science and Technology, Nkpolu-Oroworukwo, \\ Port Harcourt. \\ *Corresponding author, E-mail: ccobunwo@yahoo.com
}

\begin{abstract}
The impact of sawdust on the water quality of Elechi creek, in Port Harcourt municipality, has been investigated. Three sampling stations were established - upstream, vicinity and downstream of the main dump site of the sawdust in the water body. Various physiochemical characteristics, including temperature, Electrical conductivity, pH, Dissolved Oxygen, and Biochemical Oxygen Demand (BOD) as well as nutrients and heavy metal concentrations, of the water body have been measured using standard methods. The investigation reveals that sawdust may have altered the quality of water in the creek as changes in electrical conductivity and metal concentrations were observed.
\end{abstract}

(c) 2011 International Formulae Group. All rights reserved.

Keywords: Water quality, surface water, heavy metals, sawdust, adsorption, physicochemical characteristics.

\section{INTRODUCTION}

Elechi creek is a creek-complex located at the south-western limit of Port Harcourt municipality of Rivers State, Nigeria and receives both municipal and industrial effluents which are eventually emptied into the Bonny River.

One of the major activities that take place along a stretch of this creek is timber logging and processing. Logs of timber of different plant species are transported, by the flow of the water current to sawmills littered at the banks of the stretch. Sawdust, generated from the milling of the logs, is washed into the water body by tidal flow. Overtime, a large heap of the sawdust has been established a few meters from the water front.

Although sawdust is biodegradable, by its unregulated discharge into the water body it may exceed its critical load and may thus pose a problem to the aquatic environment. A number of studies have been conducted on the impact of sawdust on some water bodies in Nigeria. Arimoro et al. (2007) had reported that sawmill wood wastes had a negative effect on fish distribution in their communities. Akpata (1987) had also reported 
on the negative effect of sawdust on the germination of spores of different fungi in the Lagos lagoon. A number of in vitro studies have also been carried out using sawdust as an adsorbent in the removal of metal ions from aqueous solutions (Abdel-Ghani et al., 2007). Wastes from the surroundings of the study area are discharged into the water body. These wastes include metal scraps from nearby automobile garages. The adsorptive capacity of the sawdust in, in vitro studies, have thus necessitated further investigation of the impact of sawdust, especially its adsorptive capacity in the natural aquatic environment of the Elechi creek.

\section{MATERIALS AND METHODS Study area}

Elechi creek lies between longitude $6^{\circ}$ $57^{\prime}-6^{\circ} 58^{\prime} \mathrm{E}$ and $4^{\circ} 46^{\prime}-4^{\circ} 48^{\prime}$ on the upper reaches of the Bonny estuary. It is an arm of the creek that adjoins the municipal area where sawmills abound. The creek is characterized by high sea water inflow and low freshwater input from the adjoining swamp forest. It receives municipal effluents from Diobu, a high density residential area of Port Harcourt.

\section{Methods}

Three sampling stations were established to include the upstream (Station 1), vicinity (Station 2) and downstream (Station 3) of the main dump site of the sawdust in the water body. At each of the stations, surface water was collected in two separate containers; a 2-litre polyethylene container, for the measurement of physicochemical characteristics and a $100 \mathrm{ml}$ plastic container for the measurement of heavy metal concentrations. Into the plastic container, 5 drops of concentrated $\mathrm{HNO}_{3}$ were added for the preservation of the sample.

Sampling was carried out monthly for six months (March-September, 2008) at ebbing tide periods, in order to capture the flushing effect of the ebbing tide and minimize brackish water influence (Braide et al., 2004).

At each sampling station, temperature and Dissolved oxygen (DO) were measured in situ using a mercury thermometer and the Winkler method (APHA, 1998), respectively. Other physicochemical parameters, such as Electrical conductivity, $\mathrm{pH}$ and the nutrient parameters, were measured in the laboratory employing standard methods as established by APHA (1998). Metal concentrations were determined using the BUCK Scientific Atomic Absorption Spectrophotometer (Model, 200A) using appropriate lamps and standards.

In terms of the adsorptive capability of the sawdust, the metal concentrations at Stations 1 and 3 were considered as the initial and post adsorption concentrations respectively. The \% removal of the metal ion, $\%(\mathrm{E})$, may thus be expressed as:

$\%(\mathrm{E})=\left[\left(\mathrm{C}_{\mathrm{i}}-\mathrm{C}_{\mathrm{f}}\right) / \mathrm{C}_{\mathrm{i}}\right] \times 100$,

Where $C_{i}=$ Initial concentration of the metal ion and $\mathrm{C}_{\mathrm{f}}=$ Post adsorption concentration of the metal ion.

\section{RESULTS AND DISCUSSION}

The mean values of the physicochemical parameters measured are presented in Table 1. The results show that Temperature $\left(29.5 \pm 1.39{ }^{\circ} \mathrm{C}-29.57 \pm 1.69^{\circ} \mathrm{C}\right)$ and $\mathrm{pH}(6.61 \pm 0.07-6.66 \pm 0.04)$ values did not vary considerably in the water body. The values were also within limits expected for such water bodies (RPI, 1985). The results, therefore, suggest that the presence of the sawdust did not influence these physicochemical features of the water body.

Electrical conductivity values ranged from $20200.0 \pm 11200.0 \mu \mathrm{S} / \mathrm{cm}$ in Station 3 to $25333.3 \pm 6709.2 \mu \mathrm{S} / \mathrm{cm}$ in Station 1 . Although the electrical conductivity values were high, indicative of the oligohaline nature of the water body (Obunwo et al., 2006), there was a progressive decrease along the stream 
course i.e. from Station 1 to Station 3 . Electrical conductivity measures the concentration of ions present in solution. The relative decrease in electrical conductivity at the downstream stretch may suggest that the heap of sawdust may have adsorbed some ions at the vicinity of the dump and beyond.

Mean concentrations of $\mathrm{Pb}(0.0307 \pm 0$ $013 \mathrm{mg} / \mathrm{l}), \mathrm{Cr}(0.213 \pm 0.146 \mathrm{mg} / \mathrm{l})$ and $\mathrm{Ni}$ $(0.116 \pm 0.061 \mathrm{mg} / \mathrm{l})$ in Station 1 (the upstream stretch) were higher than their respective concentrations $\mathrm{Pb} \quad(0.027 \pm 0.01 \mathrm{mg} / \mathrm{l}), \quad \mathrm{Cr}$ $(0.161 \pm 0.213 \mathrm{mg} / \mathrm{l})$ and $\mathrm{Ni}(0.085 \pm 0.064$ $\mathrm{mg} / \mathrm{l}$ ) at Station 3 (the downstream stretch). $\mathrm{Cd}$ concentration, however, showed a marginal increase at the downstream stretch $(0.020 \pm 0.015 \mathrm{mg} / 1-0.021 \pm 0.008 \mathrm{mg} / \mathrm{l})$.

The reduction of the levels of $\mathrm{Pb}, \mathrm{Cr}$ and $\mathrm{Ni}$ ions at the downstream stretch of the water body may be attributed to the presence of the sawdust which may have acted as an adsorbent upstream of Station 3.

The \% removals of the metal ions, \% (E), are thus $\mathrm{Pb}(12.05 \%), \mathrm{Cr}(24.41 \%)$ and $\mathrm{Ni}$ (26.72\%). Nitrate concentrations, which represent the nutrient factor, were also high.
The main parameters that influence metal sorption include contact time, initial metal ion concentration, amount of adsorbent and $\mathrm{pH}$ values of the solution (Abdel-Ghani et al., 2007). Several researchers have reported on varied dependence of $\mathrm{pH}$ in the removal of metal ions by sawdust and other agricultural wastes (Khan et al., 2004; Shukla et al., 2005; Habib-ur-Rehman et al., 2006; Hashem, 2007; Igwe and Abia, 2007; Abdel-Ghani et al., 2007). Optimal pH of 2 to 5 has been reported by Khan et al. (2004), Shukla et al. (2005), and Igwe and Abia (2007). On the other hand, Habib-ur-Rehman et al. (2006) and AbdelGhani et al. (2007) reported an optimal pH of 6 to 6.5 . Although, this study was carried out in the natural aquatic environment, the $\mathrm{pH}$ $(6.61 \pm 0.07-6.66 \pm 0.04)$ is slightly outside the reported value in the in vitro studies and may be responsible for the relative low adsorptive capacity of the sawdust in this study. Other factors such as contact time, initial metal ion concentration and the amount of adsorbent employed could not be adequately ascertained.

Table 1: Effect of sawdust on the water quality parameters of the Elechi creek.

\begin{tabular}{lccc}
\hline Parameter & Station 1 & Station 2 & Station 3 \\
\hline Temp ${ }^{\circ} \mathrm{C}$ & $29.57 \pm 1.69$ & $29.47 \pm 1.24$ & $29.50 \pm 1.39$ \\
Electrical & & & \\
conductivity $\mu \mathrm{S} / \mathrm{cm}$ & $25333.3 \pm 6709.2$ & $23733.3 \pm 10870.8$ & $20200.0 \pm 11200.0$ \\
$\mathrm{pH}$ & $6.61 \pm 0.07$ & $6.66 \pm 0.04$ & $6.61 \pm 0.13$ \\
$\mathrm{DO} \mathrm{mg} / \mathrm{l}$ & $6.25 \pm 0 . .22$ & $5.92 \pm 0.94$ & $5.69 \pm 0.90$ \\
$\mathrm{BOD} \mathrm{mg} / \mathrm{l}$ & $7.33 \pm 0.42$ & $6.90 \pm 0.70$ & $7.13 \pm 0.47$ \\
$\mathrm{NO}_{3}-\mathrm{N} \mathrm{mg} / \mathrm{l}$ & $8.47 \pm 3.37$ & $10.10 \pm 5.20$ & $10.47 \pm 5.37$ \\
$\mathrm{PO}_{4}-\mathrm{P} \mathrm{mg} / \mathrm{l}$ & $27.97 \pm 5.40$ & $61.50 \pm 45.27$ & $65.63 \pm 44.07$ \\
$\mathrm{~Pb} \mathrm{mg/l}$ & $0.031 \pm 0.013$ & $0.029 \pm 0.013$ & $0.027 \pm 0.10$ \\
$\mathrm{Cr} \mathrm{mg} / \mathrm{l}$ & $0.213 \pm 0.146$ & $0.200 \pm 0.179$ & $0.161 \pm 0.213$ \\
$\mathrm{Ni} \mathrm{mg/l}$ & $0.116 \pm 0.061$ & $0.101 \pm 0.60$ & $0.085 \pm 0.064$ \\
$\mathrm{Cd} \mathrm{mg/l}$ & $0.020 \pm 0.015$ & $0.022 \pm 0.013$ & $0.021 \pm 0.008$ \\
\hline
\end{tabular}



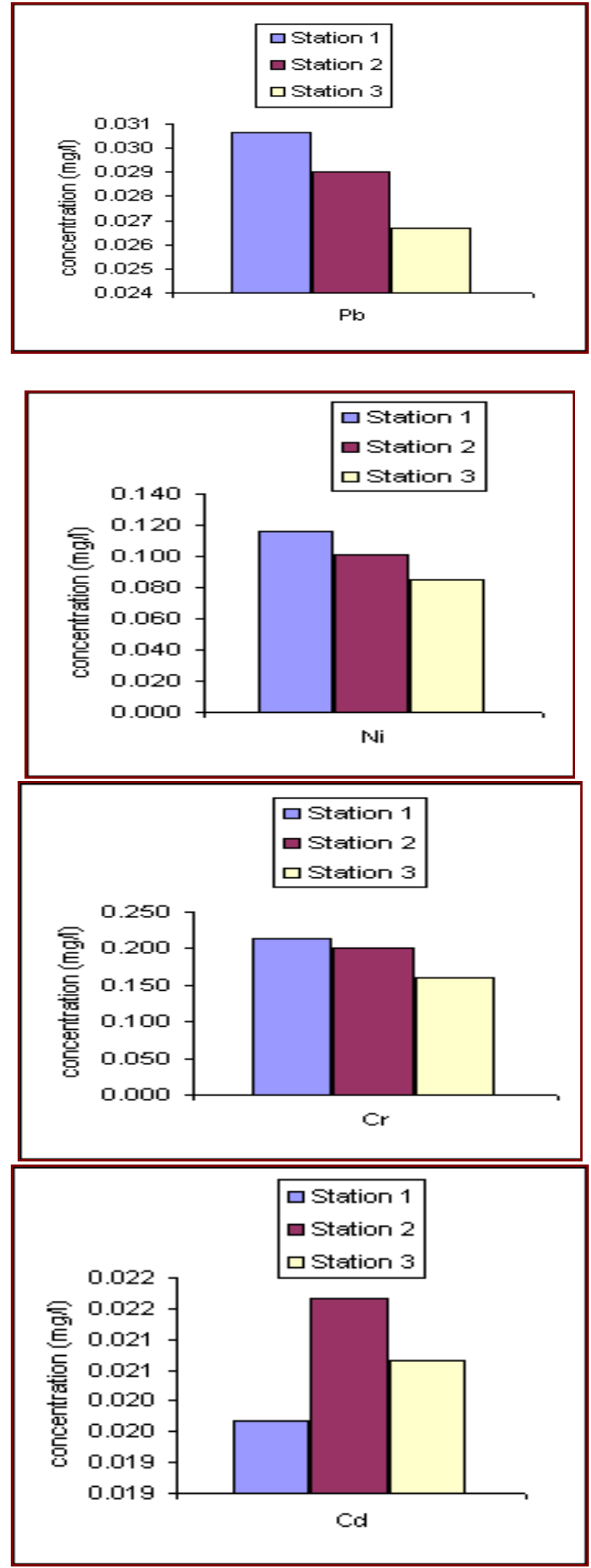

Figure 1: Effect of sawdust on metal levels along the stretch of the Elechi creek. 


\section{Conclusion}

This study suggests that dumping of sawdust may exert positive impact on water bodies, by the removal of toxic heavy metals released into the aquatic environment.

\section{REFERENCES}

APHA. 1998. Standard Methods for the Examination of Water and Wastewater $\left(20^{\text {th }}\right.$ edn). American Public Health Association (A.P.H.A).

Abdel-Ghani NT, Hefny M, El-chaghaby GAF. 2007. Removal of lead from aqueous solution using low cost abundantly available adsorbents. Int. J. Environmental Science \& Technology, 4(1): $67-73$.

Akpata TVI. 1987. Effects of sawdust pollution on the germination of fungal spores in Lagos lagoon. Environmental Pollution, 4: 37 - 48.

Arimoro FO, Okomi RB, Osalor EC. 2007. The impact of sawmill wood wastes on the water quality and fish communities of Benin River. Int. J. Science \& Technology, 2(1): 1-12.

Braide SA, Izonfuo WAL, Adiukwu PU, Chindah AC, Obunwo CC. 2004. Water quality of Miniweja stream, a swamp forest stream receiving non-point source waste discharges in eastern Niger Delta, Nigeria. Scientia Africana, 3(1): 1 - 8 .

Habib-ur-Rehman, Shakirullah M, Ahmad I, Shah S, Hameedulla H. 2006. Sorption studies of Nickel ions onto sawdust of Dalbergia sissoo. J. Chinese Chem. Soc., 53: 1045 - 1052.

Hashem MA. 2007. Adsorption of lead ions from aqueous solution by okra wastes. Int. J. Phys. Sci., 2(7): $178-184$.

Igwe JC, Abia AA. 2007. Studies on the effects of $\mathrm{pH}$ and modification of adsorbent on As (V) removal from aqueous solution using sawdust and coconut fiber. J. Chem. Soc. Nigeria, 32(2): $24-28$.

Khan NA, Ibrahim S, Subramaniam P. 2004. Elimination of heavy metals from wastewater using agricultural wastes as adsorbents. Malaysian J. Sc., 23: $43-51$.

Obunwo CC, Braide SA, Izonfuo Wal. 2006. Heavy metal burden in the Ntawogba stream, Eastern Niger Delta, Nigeria. Niger Delta Biologia, 6(2): 31 - 39.

RPI (Research Planning Institute). 1985. Environmental baseline studies for the establishment of control criteria and standards against petroleum related pollution in Nigeria.

Shukla SS, Yu LI, Dorris KL, Shukla A. 2005. Removal of nickel from aqueous solution by sawdust. J. Hazardous Materials, 121(1-3): $243-246$. 